\title{
Employability, work placements, and outward mobility: views from England and Germany.
}

\begin{abstract}
Purpose:

A central role of UK Higher Education institutes is preparing graduates for the global economy. However, UK outward mobility targets for students set in 2017 remain lower than the original set by the Bologna Process in 1999; with other European countries achieving substantially higher outward mobility. Research in this field concentrates primarily on study abroad, prompting exploration of the work placement context. This paper examines employability and outward mobility in the context of the perceived reluctance of UK students to undertake work placements abroad.
\end{abstract}

Design:

The views of undergraduate Business Management Students at Brighton Business School were compared with those of German students studying at Goethe University in Frankfurt. Staff from Brighton Business School and other UK universities were also surveyed to gather data on attitudes towards work placements abroad.

Findings:

Students from Brighton and Frankfurt displayed similar barriers to going abroad but were motivated by different drivers. The difference in these drivers is further echoed in the variations of their definitions of "employability". The research also found that lack of staff awareness or interest in placements abroad could negatively affect students' decisions about going abroad.

Research limitations:

A small-scale study such as this presents only indicative findings. Further research is necessary to explore its implications in more depth.

Originality/value:

The research provides more scope to existing literature on outward mobility by addressing work placements rather than typically focusing on study abroad. It adds value to the debate by examining placements and mobility through two different cultural lenses.

\section{Introduction}

The Bologna Process (European Union, 1999) decided that countries within the European Higher Economic Area (EHEA) would work towards a figure of at least $20 \%$ outward mobility by 2020 . Most recently the United Kingdom's outward mobility strategy (Universities UK International, 2017c), which has at its core the aim of increasing the number of students who undertake a period of work or study abroad set a target of at just over $13 \%$ of all UK-domiciled, full-time, first degree students, therefore far below the $20 \%$ established by the Bologna Process (European Union, 1999). In addition, as Findlay et al (2010) point out, where UK growth in outward mobility has stalled, other countries are recording strong increases in the number of students going abroad. Germany is one such example, and, alongside Austria and Denmark, is aiming for $50 \%$ or higher outward mobility (European Commission, 2015). With common goals of increasing outward mobility and preparing students to compete in the global market (Sweeney, 2012), it is interesting to see such variance in targets. 
It is perhaps important at this point to note that there is widespread agreement on the difficulty of accessing standardised data on international student mobility (British Council, 2015; Finger, 2011; King et al, 2010; Schomburg and Teichler, 2011; Teichler, 2009). Some studies report on degree mobile students (e.g. Brooks and Waters, 2009; Findlay et al, 2010) whilst others focus on credit mobile undergraduates (e.g. Byram and Dervin, 2008; King and Ruiz-Gelices, 2003). Further research distinguishes between Erasmus data, provider-led programmes and other instances of mobility (Findlay et al, 2009; Findlay et al, 2010). Even the parameters of the data collected by the Higher Education Statistics Agency (HESA) have changed recently from measuring minimum periods of mobility of four weeks up to until 2012-13 to a minimum of one week from 2013-14 onwards (Universities UK International, 2017a). For ease of reference, this study reflects upon credit mobile students - i.e. those who spend (or consider spending) a designated period of time abroad rather than undertaking their whole degree in another country, and will not focus solely on Erasmus statistics as a result of exploring overseas work placements rather than study abroad.

\section{The UK context}

The UK Higher Education Statistics Agency (HESA) reports that on average just 1.4\% of the UK's total undergraduate population spent time abroad during the period 2012-2015 (HESA, 2012-13; 2013-14; 2014-15). Lowe (2017) reports that while countries such as Germany are continually increasing their outward mobility targets, only one in fifteen UK undergraduates went abroad as part of their degree in 2014-15. It is evident that outward mobility here is not growing at the same rate as many other European countries.

In a recent presentation to The Office for Students, Barber (2017) notes that when addressing employability, "the challenge is to engender the skills that will allow graduates to thrive in a global economy...". Others also mention the importance of being able to compete in the European graduate job market (Findlay et al, 2006), and the ability to demonstrate international cultural awareness (Standley, 2015). However, seminal research (e.g. Pool and Sewell, 2007; Yorke, 2006) on employability makes no reference to the need for students to achieve some level of international experience to help prepare them for working life after graduation. This is reflected in many UK universities where the focus on placements available to students is often largely UK-centric and placement offices lack awareness of and interest in placements offered in other countries; a topic which we will return to later on in this paper.

Tensions surround the concept of internationalisation. Knight (2004:11) provides a useful definition, suggesting internationalisation is "the process of integrating an international, intercultural or global dimension into the purpose, functions or delivery of post-secondary education". This neutral outline reflects the broad scope of the higher education internationalisation agenda, which necessarily results in many interpretations which depend on factors such as national context and thematic understanding of the concept (Jones and de Wit, 2012). On one hand, there is an understanding that internationalisation and student mobility are intrinsically linked, with students gaining the benefits of language and intercultural skills as well as flexibility of outlook from having spent time abroad (Findlay et al, 2006). On the other hand, there are two further interpretations which believe internationalisation is operationalised by means of increased international student recruitment or through the growing "internationalisation at home" agenda (e.g. Crowther et al, 2000; Wächter, 2003).

Internationalisation at home aims to provide students with a portfolio of globally-relevant skills and knowledge without them leaving their home country (Harrison and Peacock, 2010). This generally includes but is not limited to using international students to provide alternative perspectives and 
input from other countries and cultures as well as developing an international curriculum with a global theme (ibid). This is particularly relevant in the UK context where numbers of outwardly mobile students are relatively static (King et $a l, 2010$ ) and where proponents of internationalisation at home believe that all students, not just those who are mobile have the opportunity to consider the global impact of their field of study (Jones, 2013). This is turn may impact students' beliefs about the need to spend time abroad during their studies. Indeed, a recent overview of UK higher education internationalisation found that $78 \%$ of undergraduates believe that studying alongside international peers prepares them for working in a global environment (Universities UK International, 2017b:10).

The disconnect between what employers see as imperative for graduate success in the global workplace and what many UK HEls are offering in terms of placement activity can also be seen in the overarching policies in the areas of employability and internationalisation as outlined by the Higher Education Academy. Issued in 2015, the Framework for Embedding Employability in Higher Education (HEA, 2015a) and the Framework for Internationalising Higher Education (HEA, 2015b) do not appear to echo the objectives contained within each document as one might expect. Whilst the internationalisation framework makes reference to helping prepare graduates to live in and contribute responsibly to a globally interconnected society for, among other aspects, individuals' future employability (HEA, 2015b:2), the framework for employability does not include internationalisation as a consideration. It mentions the importance of stakeholder expectations alongside enhancing students' immediate employment prospects and longer-term employability (HEA, 2015a:2) but does not define international experience as being a factor which can contribute to these end results. As a result, the gap in joined-up strategies presents a lost opportunity for reinforcing the value of international experience for students' overall employability.

Consequently, it could be argued that UK higher education institutions (HEIs) may find difficulty in meeting the desire of $60 \%$ of employers requiring graduates with international experience and competencies (Molony et al, 2011), as well as in addressing employers' concerns around the significant risks inherent in graduates' lack of intercultural skills (British Council, 2013). And "the challenge is to engender the skills that will allow graduates to thrive in a global economy..." (Barber 2017).

\section{The German context}

Mirroring difficulties in accessing standardised data in the UK is the similar, if not more problematic challenge of reviewing research data in Germany from the UK perspective. Not only is there a twotier university system in operation, with traditional universities alongside universities of applied sciences (Finger, 2011) but data are managed federally across the sixteen German states, thus hampering direct comparisons with UK institutions (Hillman, 2015). However, the German Ministry for Education and Research does produce a social survey every four years in which German students' outward mobility is addressed. It is primarily from these sources that we draw our data (e.g. Middendorff et al, 2012; Middendorff et al, 2016).

As reported by Isserstedt and Schnitzer (2002), German students have exceeded European Union targets for outward mobility since the late 1990s. A target set by the EU in 1992 determining that $10 \%$ of students should spend at least half a year abroad was met in 1997 (op cit, 7). Since then, the $20 \%$ mobility target set thereafter has also been surpassed. The period between 2000 and 2006 saw a total of $32 \%$ of students studying, working or doing a language course abroad (Middendorff et al, 2016: 19). However, the intervening years have started to witness a small decline in this total, reaching 28\% in 2016 (Middendorff et al, 2016: 19). 
Delving further into these figures reveals that study abroad participation grew from $7 \%$ in 1991 to $18 \%$ in 2012 but has since dropped to $16 \%$ in 2016. Similarly, students undertaking overseas work placements rose from 9\% in 1991 to 14\% in 2012 but in 2016 fell back to 9\% (ibid). German students studying languages abroad has also dropped off, with numbers peaking at $9 \%$ in 2003 but decreasing to only $1 \%$ in 2016 ( $i b i d)$. Nonetheless, when the overall picture is compared with figures from the United Kingdom, there still remains a difference between the two countries. As Hillman (2015: 39) notes, outward mobility has a more concentrated focus in Germany than the UK. At a time when the UK did not set any tangible outward mobility targets (Universities UK International, 2013), Germany set itself an ambitious objective of $50 \%$ of its graduates gaining international experience (Federal Ministry of Education and Research, 2014), despite seeing a small decrease in its outward mobility trends.

In terms of internationalisation the picture in Germany is somewhat different to the UK. The call for internationalisation at home is evident yet there is little in the literature about the specific German context. The research found addresses specific institutions or curricula and does not provide an overall picture. The main themes in the existing literature examine the "untapped potential" of the international aspect of much of the engineering curricula in ten German technical universities (May et al, 2013:136); while Gorges et al (2012) promote internationalisation at home through language learning in German HEls as a means of avoiding the costs of going abroad.

In contrast, internationalisation in terms of outward mobility appears a much stronger aspect within German higher education. According to a recent British Council report, Germany (alongside Malaysia) was found to have the most balanced portfolio of policies relating to internationalisation and scored "very high" across all categories measured (British Council, 2016). As Streitwieser et al (2015) attest, internationalisation in Germany can be characterised as a more co-ordinated process than in most other European education systems. This is largely down to strong support at state and federal level but also due to its successful mobility targets (ibid). Hillman (2015) also highlights that the higher education sector in Germany is strengthened by its focus on internationalisation, as do Powell and Finger (2013), who state that German HEls must meet both political expectations and increasing student demand for internationalisation and mobility.

With contrasting statistics and apparent differences in driving outward mobility forwards evident from these comparisons, questions arise as to why the pictures in each country should be at such variance. This brings us to our research questions:

- What drives higher numbers of German students to undertake a placement abroad in comparison to UK students?

- What are the limiting factors about spending time abroad?

- Are limiting factors attitudinal or informed by institutional practice?

- How is "employability" defined by students in the two countries?

\section{Outward mobility barriers and drivers}

Comparing some of the main barriers to and drivers of international mobility faced by students and their higher education institutions provides a more nuanced context in which to explore the differences between English and German students. Taking barriers first, there is agreement in the literature that factors such as costs/finance, home ties, lack of language skills, personal issues (e.g. confidence) and academic concerns are commonly found to impede students' ability or desire to spend time in another country during their degree (e.g. King et al, 2010; Powell and Finger, 2013). Other research has highlighted further barriers students may face, including administrative problems 
such as organising visas (British Council, 2015), concerns about access to quality healthcare (British Council, 2015), and issues relating to socio-economic background (Findlay et al, 2006; Netz et al, 2012). Additionally, Beerkens et al (2016) found that a main barrier was simply a lack of interest, echoing Holland and Kedia's (2003) claim that student indifference prevents an increase in the numbers of those who go abroad.

There is similar agreement when it comes to the drivers of going abroad. The main themes recurring in the literature include gaining language skills (British Council, 2015), employability/improved career prospects (Findlay et al, 2010; Deakin, 2014), improving subject knowledge (HEFCE, 2004) and developing intercultural competence/intercultural experience (Sison and Brennan, 2012; Beerkens et al, 2016). Additionally, there are factors which some researchers (e.g. Deakin, 2014) term "personal drivers" which typically include motivators such as wanting to have fun, travel opportunities, development of personal skills or just a general interest in a new culture (Van Mol and Timmerman, 2013).

\section{Research design}

In order to answer the questions above, a small-scale research project was designed to gather and compare the attitudes of students and staff at Brighton Business School and Goethe University in Frankfurt. Goethe University was chosen because of an existing link within the authors' network and because it offers some similar undergraduate degree options to those available at Brighton Business School. It was also ranked one of the world's best universities for Global Employability in the recent Times Higher Education rankings (Minsky, 2016).

An online survey was deemed the most appropriate means of capturing the data for the research, particularly because the majority of it was conducted during the vacation period where students were not easily accessible for other research methods such as interviews or focus groups. It was also the most appropriate way of gathering data from the German students due to geographical constraints. In the first instance, a pilot survey was designed and tested with students who had volunteered to complete it. Once refined and after ethics approval, it was sent to first year Brighton Business School students on Business Management (and associated pathways) degrees, having used the common method of purposive sampling, where participants are usually selected for their relevance to and knowledge of the topic under research (Denscombe, 2014:41). Students on these degree programmes are required to undertake a work placement during the third year of study and would shortly begin preparing for this so they were a good fit for the study. In the German context, students at a similar point in their degrees were identified by staff at Goethe University and a translated version (completed by a native speaker) of the same survey was distributed to them via email. The survey was designed using the online research platform Qualtrics (www.qualtrics.com). This assured anonymity of response and also the safe storage of completed surveys via a passwordprotected log-in. A total of 32 students ( 21 Brighton/11 Goethe) responded.

A similar survey (including a German version) was designed, piloted and distributed following the methods above to both academic and professional staff at Brighton Business School and at Goethe University. For comparative purposes, invitations to complete the surveys were also extended to other academic and professional staff in the UK and Germany. Fifteen responses were gathered from the UK survey but unfortunately only one German reply was received. A number of efforts were made to increase the German response rate, including emails to existing contacts, Facebook and Linkedln posts, requests to the DAAD (German Academic Exchange Service) and Erasmus+ but to no avail. Therefore, the data on staff attitudes to work placements abroad remain UK-focused. 


\section{Ethics}

Students and staff were invited by email to complete the survey. All were made aware that participation was non-compulsory and that if they did decide to provide a response, it would be anonymous (e.g. Denscombe, 2014).

\section{Data Analysis}

Collected data were analysed following Glaser and Strauss' (1967) Grounded Theory approach. All qualitative responses were subject to inductive, thematic coding whereby initial themes were identified and repeated analysis of responses allowed an initial theory to be built from the data, rather than the data being made to fit a pre-defined hypothesis. The reliability of the study was enhanced by the two researchers conducting the coding process independently of each other and deriving similar themes.

\section{Results}

Considering first the student survey, participants were asked to complete a five-point Likert scale question on the likelihood of them undertaking a work placement abroad during their degree. Data revealed that $40.91 \%$ of Brighton students would consider themselves extremely likely to undertake a work placement abroad. This compares closely to the Goethe students, of which $45.45 \%$ said the same. More substantial differences occur at the other end of the scale, with more Goethe than Brighton students expressing a neutral opinion about going abroad (18.18\% versus $4.55 \%)$. However, double the number of Brighton than Goethe students were slightly or extremely unlikely to consider a placement abroad (18.19\% vs $9.09 \%)$.

Participants were then asked to rank four statements drawn from the literature on barriers to going abroad in order of reasons for not undertaking a work placement in another country. These were:

- An overseas work placement is too expensive

- I am not confident enough to work abroad

- An overseas placement is not necessary

- I could learn the same things in the UK/Germany

Interestingly, the statements were ranked identically by the two groups of students as follows:

1. An overseas placement is not necessary

2. I could learn the same things in the UK/Germany

3. I am not confident enough to work abroad

4. An overseas work placement is too expensive

A free text box was also included for any additional barriers students might identify. These included:

- It is hard not knowing anyone (Brighton)

- Personal commitments at home (Brighton)

- Inability to fit in (Brighton)

- Not wanting to go abroad (Brighton)

- Not enough resources (Brighton)

- Costs too much time (Goethe)

- Concerns about job opportunities (Goethe)

Similar statements about the drivers of undertaking a work placement abroad were also drawn from the literature and again respondents were asked to rank them in order of what would make them 
want to do a work placement abroad. In this instance, the rankings provided by the two groups were quite different:

Table one: rankings to drivers of undertaking work placements abroad

Again, participants were also provided with a free text box to add any further drivers. These included:

- To get a feel of a job placement in a new environment (Brighton)

- To make links and get to know more people in the business industry (Brighton)

- It will be very different and we should jump at the opportunities given to us (Brighton)

- Chance to deal with a new challenge (Brighton)

- I was offered an internship (Goethe)

- It would be a beneficial experience and a new way of learning (Goethe)

Students in both groups were also asked to define "employability" and answered as follows:

Table two: students' definitions of "employability"

Moving on to the UK staff survey, participants were asked to rate the likelihood of their students undertaking a work placement in the UK versus one abroad. The interest in a UK work placement was rated at $93.75 \%$ whereas students' interest in doing one abroad was rated much lower at $56.35 \%$. Approximately one third of respondents rated their students interest in going abroad as "neutral".

The following themes were identified from responses on why UK students' lack interest in placements abroad:

- No institutional promotion or UK placement marketing is given preference

- Difficulties in raising student interest and/or awareness, particularly within Widening Participation cohorts

- Number of students asking about possibility of going abroad is small/there is a lack of initiative

- Belief that overseas opportunities are not numerous and those that are available are complex to organise

- Fear of going abroad

UK staff replied with similar reasons as found in the literature as to why students may want to go abroad; i.e. fun, adventure, travel opportunities, development of future career prospects, but were much more expansive on why they thought students might prefer to stay in the UK:

- Access to employers/former placement students

- Clearer recruitment processes

- Easier to succeed

- Fear of going abroad

- Higher UK salaries

- Less uncertainty

- "Real work" experience

- Response to good marketing of home placements

Finally, the following themes were identified from the answers to the survey questions asking about how students can find out about placements abroad; how are students prepared for undertaking an 
overseas work placement; how are the benefits of an overseas work placement communicated to students:

- Supported information provision vs independent student research expected ("there is a limit to what the team can pass on")

- Same way as UK placements/stronger focus on UK

- Little staff knowledge ("no idea", "not sure", "there is work to be done")

The comments in brackets are verbatim extracts from the survey answers.

\section{Discussion}

Although not representative, this study indicates that at the outset, when UK and German students are thinking about the opportunities for their placement year, the likelihood of going abroad is fairly similar. However, as the literature bears out in the wider context, ultimately far fewer UK students go abroad than German ones. So, we must ask what changes for UK students as they reach the final stage of decision making; and are the changes attitudinal or influenced by institutional practice?

Beerkens et al (2016:199) point out that students in Europe appear rather similar when it comes to barriers and drivers. Our data suggest this may be true of the barriers, but find that there are some interesting differences when it comes to the drivers. For instance, Goethe students rated developing international business knowledge as the top reason for undertaking a work placement abroad, whereas for Brighton students gaining/improving language skills was the primary driver. In this single answer, an immediate difference between the two groups of students can be suggested: Goethe students appear to be focused on ways to develop themselves in the workplace and Brighton students are seemingly more focused on a cultural experience. The ordering of the remaining drivers seems to bear this out, with Brighton students ranking developing international business knowledge last and Goethe students rating improving intercultural awareness last. This echoes recent British Council (2015) research (albeit about studying abroad) which found that for UK students cultural experience was a significantly stronger driver than academic or employabilityrelated factors. Conversely, Netz et al (2012) note that study-related aspects are objective factors for going abroad for German students.

Yet this still does not explain why the percentage of UK students spending time abroad during their degree is lower than that of some other European countries. A robust set of drivers as identified in this study is evident, supported by just shy of $50 \%$ of Brighton students indicating they were extremely likely to consider a placement abroad, but it is clear that from the overall picture in the UK that consideration does not always convert to action. Looking at the ways in which the students in this study define the concept of employability may provide some further answers.

As displayed in table two, Goethe students' definitions of employability vary quite differently from those offered by Brighton students. In the first instance, there is clear evidence of a more passive understanding of the concept by Brighton students. Comments such as "...making companies want to hire you" or "likeliness of employers to hire you" appear to put employability in the hands of the employers - it is something for them to identify in potential candidates. However, Goethe students appear more active in their definitions, with comments such as "experience and skills you have to offer" or "being able to adapt/switch workplaces". There is more evidence of employability being something they are responsible for.

Continuing in the same vein, analysis of the two sets of definitions also suggests a higher level of achievement orientation (Goleman et al, 2017) is encouraged in the German context. Responses 
such as "employability increases with grades and/or previous experience", "certain level of social and behavioural ability", and "achieving highly in the workplace" all reflect the importance of achievement and ability on the part of the Goethe students. Only one reference to ability was made in the responses from Brighton students and there is no mention of achievement. Instead the focus seems to rely on how much you appeal to an employer, again reflecting a somewhat more passive understanding of the concept.

Finding out why and how Goethe students displayed a more nuanced understanding of employability may help determine why Brighton students are more passive in their relation to the concept. It would have been useful to draw on data collected from German academic and professional staff at this point, but as discussed previously this was not possible so desk research was conducted instead. We found that Goethe students are provided with intensive career training (alongside individual appointments with careers staff) on a large scale. In the period May-July 2017 alone, 108 sessions were offered. Importantly, these included a high number of workshops focusing on either careers or work placements in other countries, such as:

- Applying for jobs in English

- Working in China

- Intercultural competence training

- Work placements in the EU

Goethe students are also provided with access to an extensive career planner (online and offline versions available), which include an events calendar, company insights, focus pages on specific careers or roles, and more. Lastly, Goethe students may also undertake additional training courses alongside their degree in subjects such as reading, accountancy and economics.

The extensive portfolio on offer at Goethe University can only serve to intensify students' focus on work placements and their future career. There is access to a wide variety of tools and workshops, and a strong focus on going abroad is evident. In comparison, the equivalent portfolio at Brighton is much more UK-centric, giving academic and professional staff pause for thought in how this arrangement may be made more expansive.

This leads us to the final aspect of this study; institutional practice and how far this may affect students' attitudes towards undertaking a work placement abroad. As discussed above, the focus on internationalisation within the work placements and careers services at Goethe University is evident, suggesting support and input from staff. However, despite individual pockets of well-focused activity at some institutions, our data reflect a much different picture in the UK where there is little staff knowledge and awareness of work placements abroad and an acknowledgement that "there is more to be done".

There is little in the literature which addresses UK staff attitudes to students undertaking a work placement abroad. King et al (2010) and Sweeney (2012) do look at staff opinion on internationalisation but this is largely in the context of staff mobility or the hiring of international academics. Perhaps Fielden's (2007:35) statement that for many academic staff the commitment to internationalisation can be seen as an unimportant distraction remains accurate even ten years later. Later research by $\operatorname{Sin}(2012)$ also emphasises this point and notes the low profile of the Bologna Process in England. She goes on to suggest that not only do academics see the implications of the Bologna Process as something people at upper levels need to action but also that it appears more as a threat than an opportunity (2012:395). If this is indeed the case then perhaps it is no surprise that the number of UK students undertaking work placements is low. 


\section{Recommendations}

In answer to our research questions this study finds that one possible reason for the higher outward mobility figures in Germany compared to the UK is the stronger focus on developing international business knowledge. Consequently, we suggest that more can be done in the UK context to address this.

We have identified that limiting factors to going abroad displayed by both countries in this research are similar, yet still more German students spend time abroad than those in the UK. In the light of the data collected on staff knowledge, awareness and attitudes to work placements abroad, we contend that institutional practice in the UK could well be contributing to low outward mobility figures.

Finally, we suggest that policies and frameworks surrounding employability and internationalisation need to be better aligned to successfully reinforce the ideas inherent in each of them.

\section{Conclusion}

In conclusion, we present a four-quadrant model of the factors determining outward mobility and suggest that the ideas contained in the upper-right quadrant are those that lead to successful outward mobility.

Figure one: four-quadrant model demonstrating how to increase outward mobility

\section{References}


Barber, M. (2017), "Tending the Higher Education Landscape: Priorities for the Office for Students", available at: http://www.universitiesuk.ac.uk/news/Pages/sir-michael-barber-speech-uuk-june2017.aspx (accessed 18/08/17).

Beerkens, M., Souto-Otero, M., de Wit, H. \& Huisman, J. (2016), “Similar Students and Different Countries? An Analysis of the Barriers and Drivers for Erasmus Participation in Seven Countries", Journal of Studies in International Education, Vol. 20 No. 2, pp. 184-204.

British Council (2013), "Culture At Work. The value of intercultural skills in the work place", London: British Council.

British Council (2015), "Broadening Horizons. The value of the overseas experience", London: British Council.

British Council (2016), "The Shape of Global Higher Education: National Policies Framework for International Engagement", London: British Council.

Brooks, R. and Waters, J. (2009), "International Higher Education and the Mobility of UK Students", Journal of Research in International Education, Vol. 8 No. 2, pp. 191-209.

Byram, M. and Dervin, F. (2008), Students, staff and academic mobility in higher education, Cambridge Scholars Publishers, Newcastle.

Crowther, P., Joris, M., Otten, M, Nilsson, B., Teekens, H. \& Wächter, B. (2000), “Internationalisation at home: a position paper", European Association for International Education, Amsterdam.

Deakin, H. (2014), "The drivers to Erasmus work placement mobility for UK students", Children's Geographies, Vol. 12 No. 1, pp. 25-39.

Denscombe, M. (2014) The Good Research Guide: For Small-Scale Social Research Projects, McGrawHill Education, London.

European Commission/EACE/Eurydice (2015), The European Higher Education Area in 2015: Bologna Process Implementation Report, Publications Office of the European Union, Luxembourg.

European Union (1999), The Bologna Declaration of 19 June 1999, Joint declaration of the European Ministers of Education, Bologna.

Federal Ministry of Education \& Research (2014), International Cooperation action plan: summary of the central points, BMBF, Berlin.

Fielden, J. (2007), Global Horizons for UK Universities. The Council for Industry and Higher Education, London.

Findlay, A., King, R., Stam, A., \& Ruiz-Gelices, E. (2006), “Ever Reluctant Europeans. The changing geographies of UK students studying and working abroad", European Urban and Regional Studies, Vol. 13 No. 4, pp. 219-318.

Findlay A., Geddes, A. \& Smith, F. (2009), Motivations and experiences of UK students studying abroad: Summary metadata report. DIUS, London.

Findlay, A., King, R., Geddes, A., Smith, F., Stam, A., Dunne, M., Skeldon, R. \& Ahrens, J. (2010), Motivations and Experiences of UK Students Studying Abroad. BIS Research Paper No. 8. University of Dundee. 
Finger, C. (2011), "The social selectivity of international mobility among German university students: a multi-level analysis of the impact of the Bologna process", WZB Discussion Paper, No. SP 12011 503.

Glaser, B. \& Strauss, A. (1967), The discovery of grounded theory: strategies for qualitative research, Aldine, Chicago.

Goleman, D., Davidson, R., Druskat, V. and Boyatzis, R. (2017), Achievement Orientation: A Primer, Key Step Media, Michigan.

Gorges, J., Kandler, C., and Bohner, G. (2012), “Internationalization at home: Using learning motivation to predict students' attitudes toward teaching in a foreign language, International Journal of Education Research, Vol. 53, pp. 107-116.

Harrison, N. and Peacock, N. (2010), "Cultural distance, mindfulness and passive xenophobia: using Integrated Threat Theory to explore home higher education students' perspectives on "internationalisation at home"”, British Educational Research Journal, Vol. 36 No. 6, pp. 877-902.

Higher Education Academy (2015a), The framework for embedding employability in higher education. York.

Higher Education Academy (2015b), The framework for internationalising higher education. York.

Hillman, N. (2015,) Keeping up with the Germans?: A comparison of student funding, internationalisation and research in UK and German universities, Higher Education Policy Institute, Oxford.

Holland, K.M. and Kedia, B.L. (2003), "Internationalising Business Students through the Study Abroad Experience: opportunities and challenges", Study Abroad, Vol 13, pp. 115-139.

Isserstedt, W. \& Schnitzer, K. (2002), Internationalisierung des Studiums - Ausländische Studierende in Deutschland - Deutsche Studierende im Ausland, BMBF, Bonn.

Jones, E. (2013), "Internationalisation and employability: the role of intercultural experiences in the development of transferable skills", Public Money \& Management, Vol. 33 No. 2, pp.95-104.

Jones, E. and de Wit, H. (2012), "Globalization of Internationalization: Thematic and Regional Reflections on a Traditional Concept", The International Journal of Higher Education and Democracy, Vol. 3, pp. 35-54.

King, R. and Ruiz-Gelices, E. (2003), "International student migration and the European 'year abroad", International Journal of Population Geography, Vol. 9, pp.229-52.

King, R., Findlay, A., \& Ahrens, J. (2010), International student mobility literature review, HEFCE, Bristol.

Knight, J. (2004), "Internationalization remodelled: definition, approaches, and rationales", Journal of Studies in International Education, Vol. 8 No. 1, pp. 5-31.

Lowe, R. (2017), “Gone International - the benefits of students volunteering, working or studying abroad", available at: http://www.universitiesuk.ac.uk/blog/Pages/Gone-International.aspx (accessed 05.05.17).

May, D., Lensing, K. \& Tekkaya A.E. (2013), “Internationalization as a topic in higher engineering education: a quantitative content analysis examining the engineering curricula from ten German 
technical universities", paper presented at Global Engineering Education Conference (EDUCON), $10^{\text {th }}-13$ April 2016, available at:

http://ieeexplore.ieee.org/abstract/document/7474544/?reload=true (accessed 11.08.17).

Middendorff, E., Apolinarski, B., Poskowsky, J., Kandulla, M. \& Netz, N. (2012), Die wirtschaftliche und soziale Lage der Studierende in Deutschland 2012. 20. Sozialerhebung des Deutschen Studentenwerks, BMBF, Berlin.

Middendorff, E., Apolinarski, B., Becker, K., Bornkessel, P., Brandt, T., Heißenberg, S. \& Poskowsky, J. (2016), Die wirtschaftliche und soziale Lage der Studierende in Deutschland 2016. 21. Sozialerhebung des Deutschen Studentenwerks, BMBF, Berlin.

Minsky, C. (2016), "The Global University Employability Ranking 2016, Times Higher Education", available at: https://www.timeshighereducation.com/features/global-university-employabilityranking-2016 (accessed 05/05/17)

Molony, J., Sowter, B. \& Potts, D. (2011), QS Global Employer Survey Report 2011. How Employers Value an International Study Experience, QS Quacquarelli Symonds Ltd, London.

Netz, N., Orr, D., Gwosć, C., Huß, B., (2012), What deters students from studying abroad? Evidence from Austria, Switzerland, Germany, The Netherlands and Poland, Institut für Hochschulforschung, Hannover.

Pool, L.D. \& Sewell, P. (2007), "The key to employability: developing a practical model of graduate employability", Education + Training, Vol. 49 No. 4, pp. 277-289.

Powell, J. and Finger, C. (2013), "The Bologna Process's Model of Mobility in Europe: the relationship of its spatial and social dimensions", European Educational Research Journal, Vol. 2, pp. 270-285.

Sin, C. (2012), "Academic Understanding of and Responses to Bologna: a three-country perspective", European Journal of Education, Vol. 47 No. 3, pp. 392-404.

Sison, M.D. and Brennan, L. (2012), "Students as global citizens: strategies for mobilizing studies abroad", Journal of Marketing for Higher Education, Vol. 22 No. 2, pp. 167-181.

Standley, H.J. (2015), "International mobility placements enable students and staff in Higher Education to enhance transversal and employability-related skills", FEMS Microbiology Letters, Vol. 362, pp. 1-5.

Streitwieser, B., Olson, J., Burkhart, S. \& Klabunde, N. (2015), “Coordinated German Internationalization: Broadening Perspectives", International Higher Education, Vol. 83, pp. 24-26.

Sweeney, S. (2012), Going Mobile: Internationalisation, mobility and the European Higher Education Area, Higher Education Academy, York.

Teichler, U. (2009), "Internationalisation of higher education: European experiences", Asia Pacific Education Review, Vol. 10 No.1, pp. 93-106.

Universities UK International (2013), UK Strategy for Outward Mobility, HEFCE, Bristol.

Universities UK International (2017a), Gone International: mobility works. Report on the 2014-15 graduating cohort, Universities UK International, London.

Universities UK International (2017b), International Facts \& Figures: Higher Education May 2017, Universities UK International, London. 
Universities UK International (2017c), UK Strategy for Outward Student Mobility 2017-2020, Universities UK International, London.

Van Mol, C. and Timmerman, C. (2013), "Should I Stay or Should I Go? An Analysis of the Determinants of Intra-European Students Mobility", Population, Place and Space, Vol. 20 No. 5, pp. 465-479.

Yorke, M. (2006), Employability in Higher Education: What it is - what it is Not, Higher Education Academy, York. 


\section{Increased outward mobility}

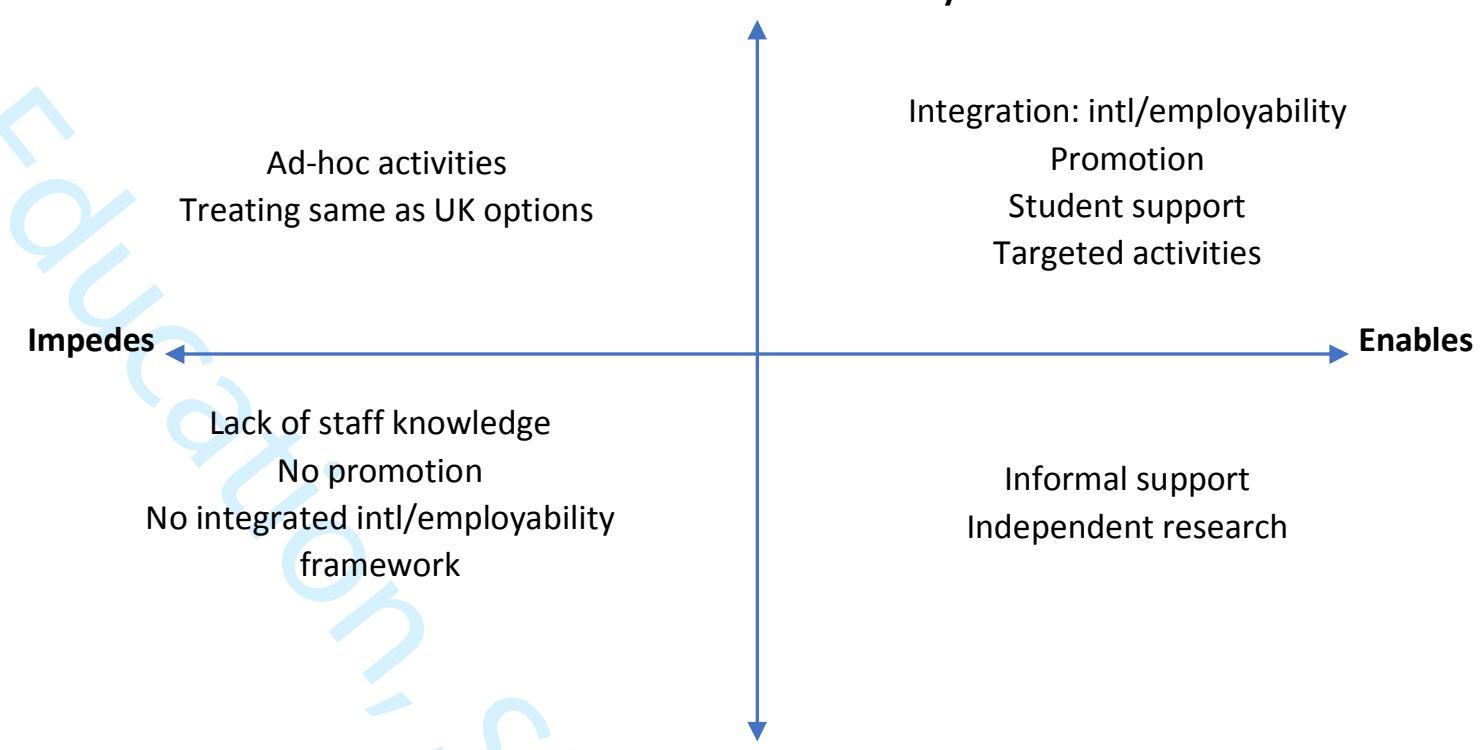

Reduced outward mobility 
1. Gain/improve language skills

2. Improve intercultural awareness

3. Make myself more employable

4. Develop international business knowledge
Goethe students

1. Develop international business knowledge

2. Gain/improve language skills

3. Make myself more employable

4. Improve intercultural awareness

Table one: rankings to drivers of undertaking work placements abroad

\begin{tabular}{|c|c|}
\hline $\begin{array}{l}\text { Brighton students } \\
\text { Experience, attitudes and behaviours making } \\
\text { companies want to hire you }\end{array}$ & $\begin{array}{l}\text { Goethe students } \\
\text { The experience and skills you have to offer }\end{array}$ \\
\hline Skills needed to get a job & $\begin{array}{l}\text { Flexibility and being able to adapt/switch } \\
\text { workplaces }\end{array}$ \\
\hline & $\begin{array}{l}\text { Educational status: employability increases with } \\
\text { grades and/or previous experience }\end{array}$ \\
\hline Likeliness of employers to hire you & A certain level of social and behavioural ability \\
\hline $\begin{array}{l}\text { How much you appeal to an employer/your } \\
\text { market value }\end{array}$ & Achieving highly in the workplace \\
\hline
\end{tabular}

Table two: students' definitions of "employability" 